Pandey et al., Afr J Tradit Complement Altern Med. (2014) 11(2):439-446

http://dx.doi.org/10.4314/ajtcam.v11i2.30

\title{
IMPROVED GROWTH AND COLCHICINE CONCENTRATION IN GLORIOSA SUPERBA ON MYCORRHIZAL INOCULATION SUPPLEMENTED WITH PHOSPHORUS-FERTILIZER
}

\section{Devendra Kumar Pandey ${ }^{1}$, Tabarak Malik ${ }^{1}$, Abhijit Dey ${ }^{2}$, Joginder Singh $^{1}$ and R.M. Banik $^{3}$}

${ }^{1}$ Department of Biotechnology, School of Biosciences and Biotechnology, Lovely Professional University.Phagwara144402, India, ${ }^{2}$ Department of Botany, Presidency University, Kolkata, ${ }^{3}$ School of Biochemical Engineering, Institute of Technology, Banaras Hindu University, Varanasi - 221005, India.

*E-mail: dkpandey1974@yahoo.co.in

\begin{abstract}
Background: Gloriosa superba produces an array of alkaloids including colchicine, a compound of interest in the treatment of various diseases. The tuber of Gloriosa superba is a rich source of colchicine which has shown anti-gout, anti-inflammatory, and anti-tumor activity. However, this promising compound remains expensive and Gloriosa superba is such a good source in global scale. Increase in yield of naturally occurring colchicine is an important area of investigation.

Materials and Methods: The effects of inoculation by four arbuscular mycorrhizal (AM), fungi, Glomus mossae, Glomus fasciculatum, Gigaspora margarita and Gigaspora gilmorei either alone or supplemented with P-fertilizer, on colchicine concentration in Gloriosa superba were studied. The concentration of colchicine was determined by high-performance thin layer chromatography.

Results: The four fungi significantly increased concentration of colchicine in the herb. Although there was significant increase in concentration of colchicine in non-mycorrhizal P-fertilized plants as compared to control, the extent of the increase was less compared to mycorrhizal plants grown with or without P-fertilization. This suggests that the increase in colchicine concentration may not be entirely attributed to enhanced P-nutrition and improved growth. Among the four AM fungi Glomus mossae was found to be best. The total colchicine content of plant (mg / plant) was significantly high in plants inoculated with Glomus mossae and $25 \mathrm{mg} \mathrm{kg}^{-1}$ phosphorus fertilizer $(348.9 \mathrm{mg} / \mathrm{plant})$ while the control contain least colchicine (177.87 mg / plant).
\end{abstract}

Conclusion: The study suggests a potential role of AM fungi in improving the concentration of colchicine in Gloriosa superba tuber.

Key words: Gloriosa superba, colchicine, Arbuscular mycorrhiza, Phosphorus fertilizer .

\section{Introduction}

Gloriosa superba L. (Liliaceae) is an ornamental climbing herb native of tropical Asia, and Africa often been cultivated for its beautiful flowers. The roots and tubers of this plant have been used in traditional Indian medicine for the treatment of gout, rheumatic arthritis, diseases of the skin and liver, and several other purposes (Finnie and Staden, 1994). Since the detection of colchicine in Gloriosa (Clewer et al, 1915), a number of researchers have suggested that Gloriosa could serve as a commercial source of colchicine (Sarin et al, 1977; Srivastava and Chandra, 1977), as the colchicine content in the genera Colchicum has been reported to be lower than in Gloriosa (Bellet and Graignault, 1985). Colchicine, the main alkaloid of Gloriosa superba, was a useful agent in the treatment of acute attacks of gout (Robert et al., 1987) cirrhosis of the liver (Kershowtrich et al, 1988) and familial Mediterranean fever (Goldfinger et al. 1972). Colchicine and its analogues were used clinically for the treatment of certain forms of leukemia and solid tumers (Alexander et al, 1994). Due to its potent affinity for tubulin; colchicine is used in biological and breeding studies to produce polyploidy, multiplication of the chromosomes in cell nucleus and in tubulin binding assays as a positive control (Trease and Evans, 1983).

Since the discovery of colchicine in Gloriosa, its commercial importance has increased as it has a higher content of colchicine than Colchicum (Yoschida, 1988a; Finnie \& van Staden 1994). In horticultural practice, vegetative propagation of Gloriosa is commonly used but the growth is very low (Kranse 1986). There are limited numbers of reports on tissue culture of G. superba (Finnie and van Staden, 1989). The amount of colchicine recorded in tissue cultures of Gloriosa was 10-25 times lower than those found in plants growing in vivo (Hayashi et al. 1988, Finnie \& van Staden 1991). Therefore, improvement in naturally occurring colchicine yield is an important area of investigation.

Arbuscular mycorrhizal (AM) fungi are known to play a pivotal role in the nutrition and growth of plants in many production-orientated agricultural systems, but little is known about their potential effect on secondary metabolites in medicinal and aromatic plants (Copetta et al. 2006; Kapoor et al. 2002a, b, 2004; Khaosaad et al. 2006, Sailo and Bagyaraj, 2005). Gloriosa superba is usually both mycorrhizal and responsive to the symbiosis (Blanke et al. 2005). To our knowledge, no study has been carried out on the effect of AM in the production of colchicine in Gloriosa superba. We therefore conducted an experiment with the objectives to (1) compare the effects of four AM fungi Glomus mossae, Glomus fasciculatum Gigaspora margarita and Gigaspora gilmorie on plant growth and production of colchicine in Gloriosa superba and (2) determine if phosphate fertilizers would alter AM effects on colchicine production in Gloriosa superba.

\section{Material and Methods Experimental Design}

The Glass house study was carried out in year 2007, at the medicinal plant garden, B.H.U., Varanasi, India $\left(25^{\circ} 18^{\prime \prime} \mathrm{N}, 83^{\circ} 50^{\prime \prime} \mathrm{E}\right)$. The experimental location experiences a semi-arid tropical climate. The soil of the experimental field was sandy loam texture, organic electrical conductivity $0.42 \mathrm{dS} \mathrm{m}^{-1}$, available carbon $0.38 \%$, available nitrogen $180 \mathrm{~kg} \mathrm{ha}^{-1}$, available phosphorus $21 \mathrm{~kg} \mathrm{ha}{ }^{-1}$ and $\mathrm{pH} 7.3$. Plants used in the study were propagated from a V- shaped tuber of Gloriosa superba. One tuber was planted in each pot for rooting in the first week of May 2007. 
http://dx.doi.org/10.4314/ajtcam.v11i2.30

Tubers were sprouted in the month of July and healthy, profusely rooted, 30 days old plants were transplanted in the polybags of 1.5 litre volume each. After 180 days, December, 2007, plants were harvested from the polybags. Light irrigation was provided just after transplanting. The plants were allowed to grow and no fertilizer or pesticide was added to the soil during the course of the experiment. The aerial and underground tuber parts of the plants were separated and the different parts were washed with tap water, shade dried and kept in cellulose bags for further experiment. Two experiments were conducted: (1) Screening of best AM fungi influencing the growth and colchicine content of Gloriosa superba and (2) The second experiment were conducted to study effect of best AMF and different levels of $\mathrm{P}$ fertilizer [super phosphates $\left(\mathrm{P}_{2} \mathrm{O}_{5}\right)$ ] on growth and colchicine content of Gloriosa superba. The $2 \times 4$ Full factorial experiment was designed with two mycorrhizal conditions viz nonmycorrhizal and inoculated with Glomus mossae combined with four concentrations of phosphorus $\left(0,25,50\right.$ and $100 \mathrm{mg} \mathrm{kg}^{-1} \mathrm{P}$-fertilizer) in the soil. The treatment combinations were arranged in a completely randomized design, with 10 plants per treatment. The experiment was done in triplicate.

\section{Mycorrhizal Inoculation}

Pot cultures of Glomus mossae, Glomus fasciculatum, Gigaspora margarita and Gigaspora gilmorei plants for 6 months. Five hundred grams of soil inoculum (50 spores/10 g soil), along with $200 \mathrm{mg}$ of chopped AM Zea mays roots (AM colonization level $80 \%$ ), was placed in furrows made with the help of a drill in each polybags before planting the rooted tuber of Gloriosa superba. Nonmycorrhizal inoculum consisted of $500 \mathrm{~g}$ rhizosphere soil and $200 \mathrm{mg}$ chopped nonmycorrhizal sorghum roots obtained by sowing surface sterilized seeds of Zea mays in pot containing autoclaved soil.

\section{Growth parameter and Nutrient estimation in Plants}

Plants were grown under natural field conditions for 180 days. For each parameter studied, six plants were randomly harvested from polybags of each treatment. Roots were washed and dried on blotting paper. Fresh weight of shoot per plant was determined. Shoot samples were oven-dried at $72^{\circ} \mathrm{C}$ for $48 \mathrm{~h}$ for determination of dry weight $(\mathrm{g} / \mathrm{plant})$. Later, the same dried shoot samples were analyzed for their mineral concentration. Leaf sugar was extracted by the method of Angelov et al (1993). Total soluble sugar was determined using the method of Riazi et al (1985). Oven dried leaf was ground and sieved through $0.5 \mathrm{~mm}$ sieve. $0.2 \mathrm{~g}$ ground material was digested in a triple acid mixture $\left(\mathrm{HNO}_{3}, \mathrm{H}_{2} \mathrm{SO}_{4}\right.$ and $60 \% \mathrm{HClO}_{4}$ in a ratio of 10:1:4), for analysis of phosphorus. The amount of phosphorus in the digested sample was estimated by molybdenum blue method (Allen, 1989). The nitrogen content of leaf was measured using the semi-micro Kjeldahl method (Bremmer and Mulvaney, 1982). Leaf chlorophyll content was determined at harvest $(\mathrm{n}=3)$, by extraction of chlorophyll with acetone (Harborne, 1998). Procedure was modified as follows, representative semi-mature leaflets were collected and surface area was determined. Leaflets were placed in $5 \mathrm{~mL}$ of $80 \%$ acetone and stored in the dark for $7 \mathrm{~d}$ at $4{ }^{\circ} \mathrm{C}$. Supernatant was quantified with a spectrophotometer (Perkins-Elmer UV/Vis Spectrophotometer), at 645 and $663 \mathrm{~nm}$, and compared to an $80 \%$ acetone blank standard. Total chlorophyll content was expressed as $\mathrm{mg} / \mathrm{g}$ dry wt. of leaf.

\section{Assessment of Arbuscular Mycorrhizal development}

Assessment of roots for AM colonization was made at the end of the experiment by random sampling of roots. Percentage mycorrhizal root colonization was estimated following grid line intersect method (Giovanetti \& Mossae, 1980) after staining the roots by the method of Philips \& Hayman (1970).

\section{Colchicine extraction and estimation}

The amount of extracted colchicine from Gloriosa superba tuber was analyzed by high performance thin layer chromatography (HPTLC), as described by Bodoki et al, 2004 [26] with some modification. Standard colchicine and the samples were spotted on percolated silicagel $\mathrm{F}_{254}$ aluminum plate (E-Merck grade) as narrow bands $4 \mathrm{~mm}$ wide at a constant rate of $10 \mu \mathrm{s} \mathrm{s}^{-1}$ using Camag Linomat IV model applicator under nitrogen atmosphere. A mixture of toluene and methanol $(85: 15 \mathrm{v} / \mathrm{v})$, was used as the mobile phase. For detection and quantification of colchicine (at $\left.R_{\mathrm{f}} 0.2\right)$, scanning densitometry was performed using a Camag TLC scanner with CATS 4 software, in reflectance (at 360nm) and fluorescence modes (Hg lamp, $254 \mathrm{~nm})$.

\section{Statistical Design}

The experiment was a $2 \times 4$ factorial in a completely randomized design with two AMF levels (AMF and Non-AMF), and four levels of P: $0,25,50$, and $100 \mathrm{mg} \mathrm{Pg}^{-1}$. There was one rooted Gloriosa superba per polybags, with each polybag as a single replicate. Data were analyzed using General Linear Model by using MINITB (15 version) software. The numbers of replications were: growth data $(\mathrm{n}=9)$ ), $\mathrm{P}$ analysis $(\mathrm{n}=3)$, chlorophyll content $(n=3)$, colchicines content $(n=5$, and AMF observations $(n=675)$. Experiments were done in two run. All statistical analyses were performed with Statistical Package MINITAB (version 15).

\section{Results \\ Experiment 1: Screening of best AM fungi \\ Plant growth parameter, root colonization and nutrient concentration}

Both the Glomus species successfully colonized the roots of Gloriosa superba (Table 1). No AM colonization was observed in those plant roots that were not inoculated with AM fungi. Percentage of root colonization varied between the fungi (Table I). AM fungal inoculation had a significant effect on all measured plant growth variables i.e tuber dry biomass, aerial shoot dry biomass and seed dry biomass (Table I). However, the level to which plant growth was enhanced varied between the fungal inoculants Glomus mossae-colonized plants performed consistently better than $G$. fasciculatum and other Am fungi-inoculated and non-mycorrhizal plants. Mycorrhizal plants consistently accumulated more quantities of nitrogen, 
Pandey et al., Afr J Tradit Complement Altern Med. (2014) 11(2):439-446

http://dx.doi.org/10.4314/ajtcam.v11i2.30

sugar, chlorophyll and phosphorus in their leaf than the non-mycorrhizal plants. Glomus mossae inoculated plants performed better than other AM fungi inoculated plants. All AM fungi inoculated plants Glomus mossae, Glomus fasciculatum Gigospora margarita and Gigospora gilmorie resulted in root colonization while control plants did not show root colonization. However Glomus mossae found to be best among all the AM fungi inoculated plants (Table IA).

Table I-A: Screening of best AMF Inoculating Gloriosa superba and their effect on growth and nutrient.

\begin{tabular}{|l|l|l|l|l|l|l|l|l|}
\hline AMF & $\begin{array}{l}\text { Tuber } \\
\text { DM }\end{array}$ & $\begin{array}{l}\text { Aerial } \\
\text { shoot } \\
\text { DM }\end{array}$ & $\begin{array}{l}\text { Seed } \\
\text { DM }\end{array}$ & $\begin{array}{l}\text { Leaf } \\
\text { Chl }\end{array}$ & $\begin{array}{l}\text { Leaf } \\
\text { N(\%DM } \\
)\end{array}$ & $\begin{array}{l}\text { Leaf P. Peaf Sugar } \\
(\% \text { DM })\end{array}$ & $\begin{array}{l}\text { \%oot } \\
\text { colonization }\end{array}$ \\
\hline Control & 37.33 & 15.6 & 0.51 & 3.11 & 1.39 & 0.21 & 2.11 & 0 \\
\hline G. mossae & 51.6 & 23.5 & 1.22 & 4.21 & 1.65 & 0.31 & 2.87 & 92 \\
\hline G. fasciculatum & 43.3 & 21.5 & 1.14 & 4.11 & 1.56 & 0.28 & 2.78 & 87 \\
\hline G. margarita & 41.3 & 18.9 & 1.11 & 3.89 & 1.55 & 0.26 & 2.54 & 79 \\
\hline G. gilmorei & 40.7 & 17.5 & 1.02 & 3.87 & 1.51 & 0.26 & 2.51 & 76 \\
\hline
\end{tabular}

Table I- B: Screening of best AMF Inoculating Gloriosa superba and their effect on colchicines content.

\begin{tabular}{|l|l|l|l|l|}
\hline Amf Inoculation & $\begin{array}{l}\text { Colchicine \% dry } \\
\text { wt. Of shoot }\end{array}$ & $\begin{array}{l}\text { Colchicine \% dry } \\
\text { wt. Of root }\end{array}$ & $\begin{array}{l}\text { Colchicine \% } \\
\text { dry wt. Of } \\
\text { seed }\end{array}$ & $\begin{array}{l}\text { Colchicine mg } \\
\text { Plant }^{-1}\end{array}$ \\
\hline Control & 0.11 & 0.41 & 0.72 & 90 \\
\hline G. mossae & 0.14 & 0.53 & 0.94 & 190.34 \\
\hline G. fasciculatum & 0.13 & 0.48 & 0.9 & 150.4 \\
\hline G. margarita & 0.12 & 0.45 & 0.88 & 125.67 \\
\hline G. gilmorei & 0.11 & 0.43 & 0.86 & 121.21 \\
\hline
\end{tabular}

Table II- A: Effect of phosphorus and arbuscular mycorrhizal fungi (AMF) on growth and nutrient of Gloriosa superba plants.

\begin{tabular}{l|l|l|l|l|l|l|l|l|l} 
TCP & AMF & $\begin{array}{l}\text { Tuber } \\
\text { DM }\end{array}$ & $\begin{array}{l}\text { Aerial } \\
\text { shoot } \\
\text { DM }\end{array}$ & seed & $\begin{array}{l}\text { Leaf } \\
\text { N(\%DM })\end{array}$ & $\begin{array}{l}\text { Leaf P. } \\
(\% \mathrm{DM})\end{array}$ & $\begin{array}{l}\text { Leaf Sugar } \\
(\% \mathrm{DM})\end{array}$ & $\begin{array}{l}\text { Chloroph } \\
\text { yll }\end{array}$ & $\begin{array}{l}\text { Root } \\
\text { colonizati } \\
\text { on }\end{array}$ \\
\hline 0 & No & 36.16 & 15.5 & 0.54 & 1.22 & 0.18 & 2.11 & 3.11 & 0 \\
\hline 25 & No & 39.66 & 17.3 & 0.62 & 1.33 & 0.24 & 2.33 & 3.24 & 0 \\
\hline 50 & No & 41.66 & 17.9 & 0.72 & 1.41 & 0.27 & 2.43 & 3.23 & 0 \\
\hline 100 & No & 41.23 & 17.8 & 0.64 & 1.36 & 0.25 & 2.32 & 3.11 & 0 \\
\hline & & & & & & & & & \\
\hline 0 & Yes & 52.00 & 23.5 & 0.54 & 1.65 & 0.31 & 2.87 & 4.23 & 92 \\
\hline 25 & Yes & 54.66 & 24.3 & 1.34 & 1.89 & 0.39 & 2.97 & 4.17 & 88 \\
\hline 50 & Yes & 58.60 & 27.6 & 1.21 & 1.79 & 0.35 & 2.93 & 4.16 & 86 \\
\hline 100 & Yes & 56.50 & 25.7 & 1.12 & 1.77 & 0.34 & 2.91 & 4.16 & 77 \\
\hline $\mathbf{P}$ & AMF & $* * *$ & $* *$ & & $* *$ & $* *$ & $*$ & $* *$ & $* *$ \\
\hline & P & $* *$ & $* * *$ & & $* *$ & $* *$ & $* *$ & $* *$ & $*$ \\
\hline & AMFX P & $*$ & $*$ & & $* *$ & $*$ & $*$ & $*$ & $* *$
\end{tabular}

Significance according to ANOVA, NS, ******, non-significant and significant $\mathrm{P} \leq 0.05,0.01,0.001$, respectively Means (n=3).

Table II- B: Effect of phosphorus and arbuscular mycorrhizal fungi (AMF) on colchicines content of Gloriosa superba plants

\begin{tabular}{|l|l|l|l|l|l|}
\hline $\begin{array}{l}\text { Phosph } \\
\text { orus }\end{array}$ & G. mossae & $\begin{array}{l}\text { Colchicine \% } \\
\text { dry wt. of } \\
\text { shoot }\end{array}$ & $\begin{array}{l}\text { Colchicine \% dry wt. } \\
\text { of tuber (root) }\end{array}$ & $\begin{array}{l}\text { Colchicine \% } \\
\text { dry wt. of seed }\end{array}$ & $\begin{array}{l}\text { Colchicines mg } \\
\text { plant }-1\end{array}$ \\
\hline 0 & No & 0.09 & 0.44 & 0.78 & 177.87 \\
\hline 25 & No & 0.12 & 0.46 & 0.81 & 179.97 \\
\hline 50 & No & 0.14 & 0.51 & 0.81 & 184.7 \\
\hline 100 & No & 0.14 & 0.49 & 0.76 & 178.9 \\
\hline & & & & & \\
\hline 0 & Yes & 0.12 & 0.56 & 0.94 & 342.6 \\
\hline 25 & Yes & 0.14 & 0.65 & 0.96 & 348.9 \\
\hline 50 & Yes & 0.16 & 0.61 & 0.93 & 345.7 \\
\hline 100 & Yes & 0.15 & 0.61 & 0.91 & 343.8 \\
\hline P & AMF & $* *$ & $*$ & $* * *$ & $* *$ \\
\hline & P & $* *$ & $* *$ & $* *$ & $* *$ \\
\hline & AMFXP & $* *$ & $*$ & $*$ & $* *$ \\
\hline
\end{tabular}

Significance according to ANOVA, NS, ${ }^{*}{ }^{* *},{ }^{* * *}$, non-significant and significant $\mathrm{P} \leq 0.05,0.01,0.001$, respectively. Means ( $\mathrm{n}=3$ ). 


\section{Concentration of colchicine in different parts of Gloriosa superba}

Concentration of colchicine in the tuber, aerial shoot and seeds were significantly high in all AMF treatments compared to controls. The colchicine concentration was highest in Glomus mossae plants, which has significantly higher concentration of colchicine when compared with the other AMF inoculated plants. The next best treatments were Glomus fasciculatum, Gigospora margarita and Gigospora gilmorie treated Gloriosa superba plants (Table I-B).

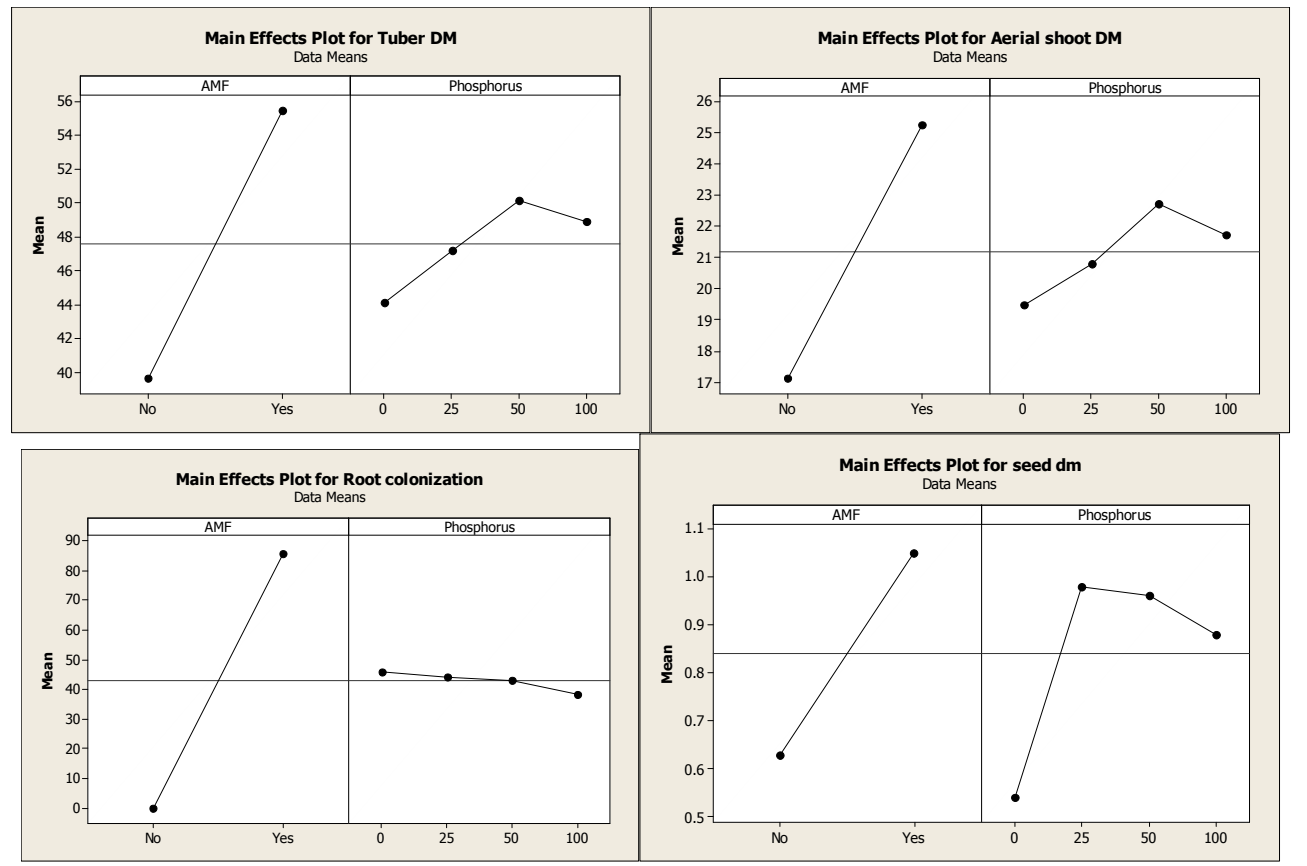

Figure I-A: Main effect plot of different AM fungi and phosphorus on growth parameters and mycorrhization of Gloriosa superba
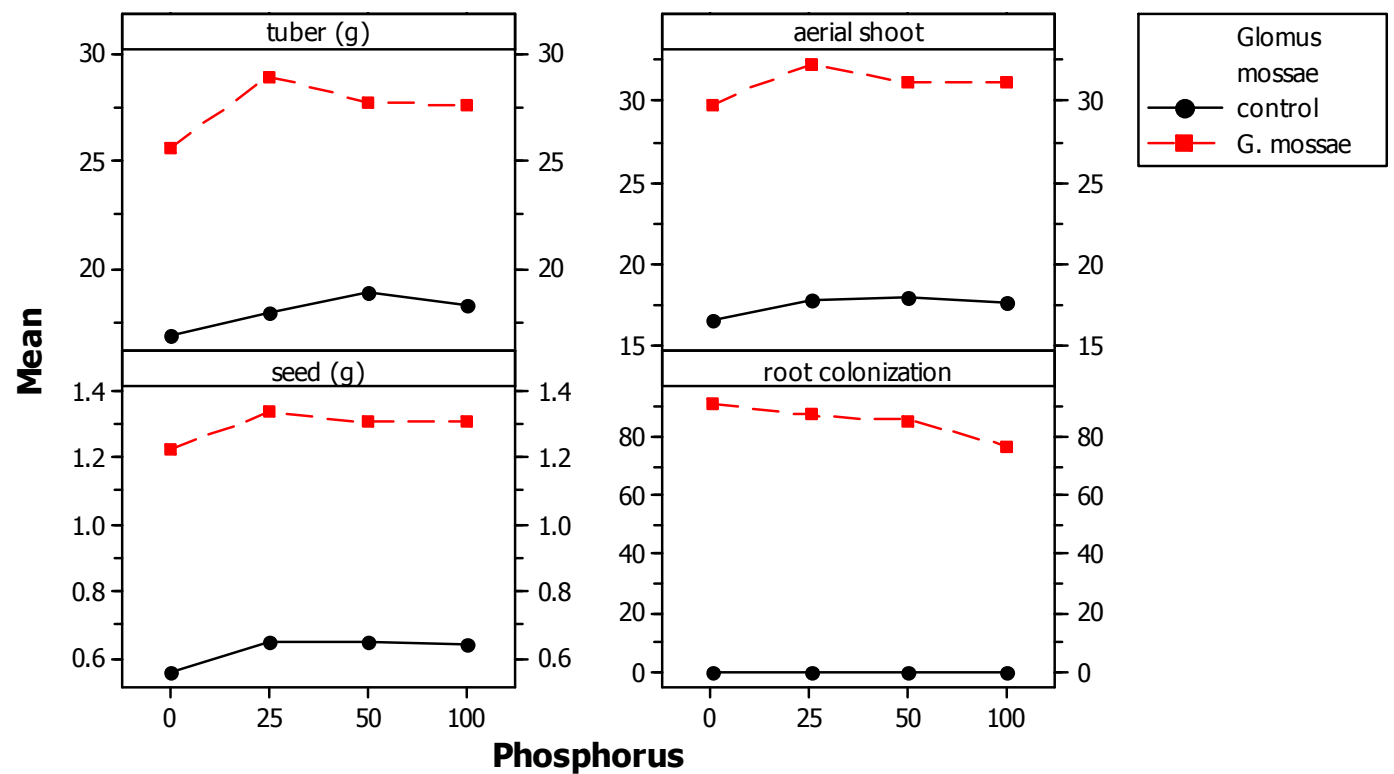

Figure I-B: Graph of different AM fungi and phosphorus on growth parameters and mycorrhization of Gloriosa superba

Effect of Glomus mossae and different level of phosphorus fertilizers on Gloriosa superba Plant Growth, root colonization and nutrient concentration in Gloriosa superba

AM fungal inoculation and/or phosphorus fertilization had a significant effect on all measured plant growth variables (Table II A). However, the level to which plant growth was enhanced varied between the different levels of $\mathrm{P}$ applications. Glomus mossae-colonized plants performed consistently better than non-mycorrhizal P-fertilized plants. Mycorrhizal inoculation of plants in the $25 \mathrm{mg} \mathrm{kg}^{-1} \mathrm{P}$ - soil further increased the tuber and aerial dry biomass and found to be best when compared with the non-mycorrizal plants treated with different levels of P fertilizers and mycorrhizal 
Pandey et al., Afr J Tradit Complement Altern Med. (2014) 11(2):439-446

http://dx.doi.org/10.4314/ajtcam.v11i2.30

plants treated with different levels of $\mathrm{P}$ fertilizers. The treatment $\mathrm{GM}+25 \mathrm{mg} \mathrm{kg}^{-1} \mathrm{P}$ produced up to $51 \%$ more tuber biomass than non-inoculated control plants (Fig II-A and II-B). Mycorrhizal plants with different level of P consistently accumulated more quantities of phosphorus, nitrogen and sugar in their leaves than the non-mycorrhizal plants with different level of P. However, the differences were not significant in plants grown in Pfertilized soil (Table II A and B). Glomus mossae $+25 \mathrm{mg}$ P applied plants resulted in higher concentrations of $\mathrm{P}, \mathrm{N}$ and sugar in leaves when compared with the other AMF+ $\mathrm{P}$ and $\mathrm{P}$ applied plants. Mycorrhizal inoculation $+\mathrm{P}$-fertilizer and P-fertilizer application alone significantly influence the concentrations of chlorophyll. Among AM fungi + P-fertilizer together AMF $+25 \mathrm{mg}$ P resulted in significant increases in concentrations of chlorophyll compared to non AMF + P fertilizer applied plants and AMF + P applied plants. All AM fungi inoculated plants with Glomus mossae $+P$ applied plants resulted in root colonization while non -AMF + $\mathrm{P}$ applied plants did not show root colonization. However Glomus mossae+ 0 mg $\mathrm{P}$ applied plants showed maximum root colonization and found to be best among AMF + P applied plants. (Fig IIA and B)

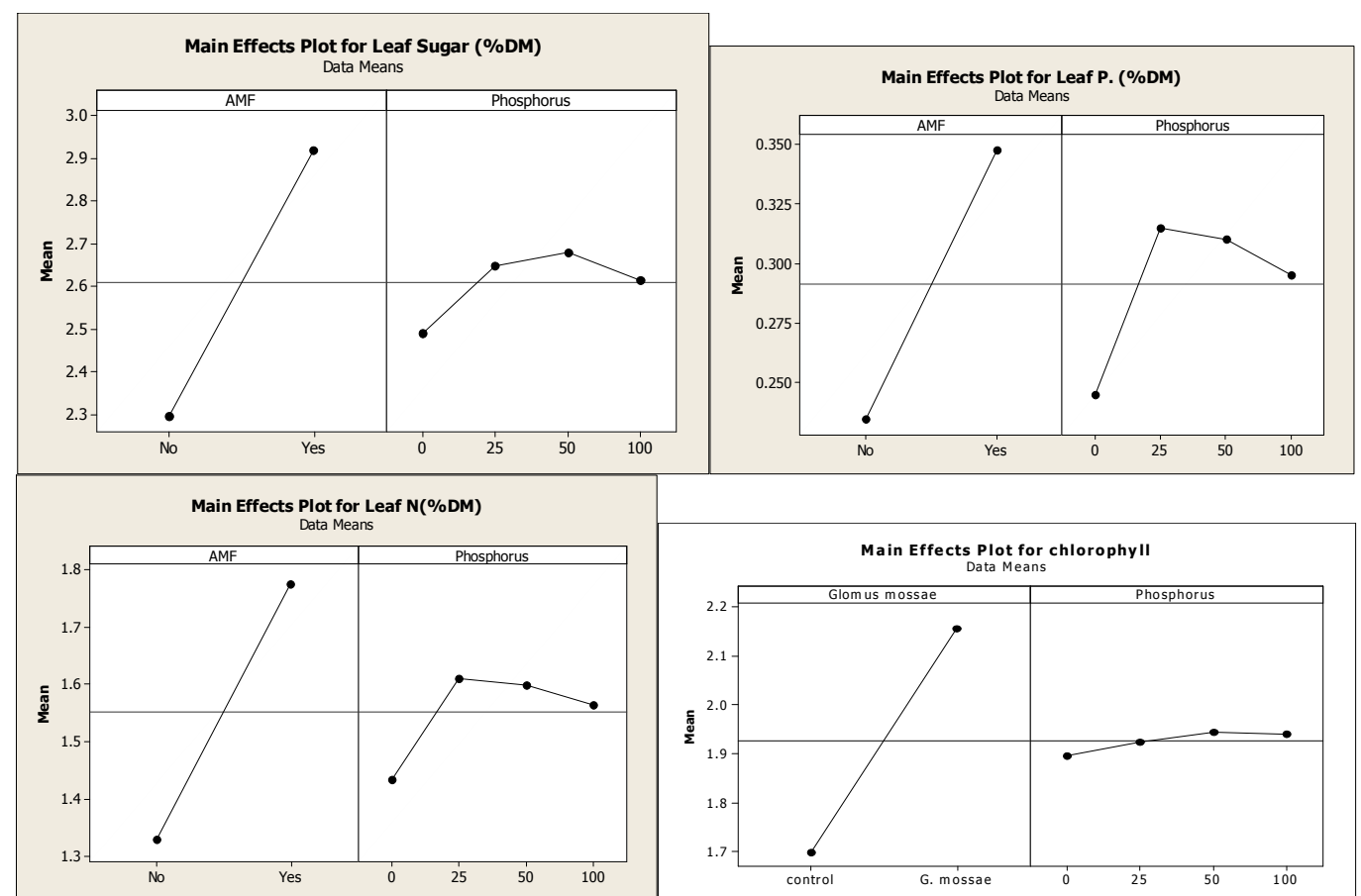

Figure II-A: Main effect plot of different AM fungi and phosphorus on foliar nutrient parameter of Gloriosa superba

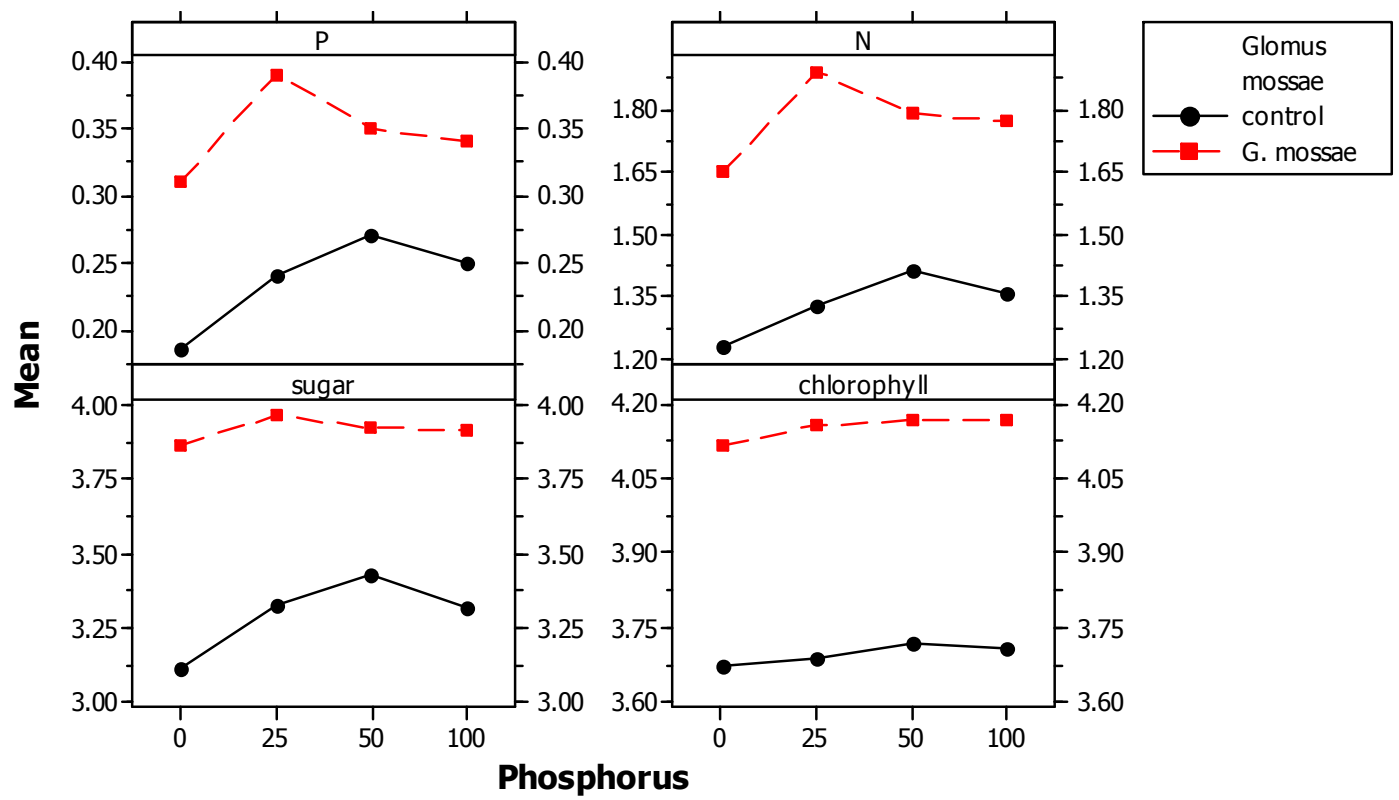

FigureII-B: Graph of different AM fungi and phosphorus on foliar nutrient parameter of Gloriosa superba

\section{Concentration of cochicine in different parts of Gloriosa superba plants}

Concentration of colchicine in the tuber was significantly higher in all AMF+P treatments compared to controls and non $\mathrm{AMF}+\mathrm{P}$ treated plants. The colchicine concentration was highest in Glomus mossae $+25 \mathrm{mg}$ P treated plants, which has significantly higher concentration of colchicine 
Pandey et al., Afr J Tradit Complement Altern Med. (2014) 11(2):439-446

http://dx.doi.org/10.4314/ajtcam.v11i2.30

when compared with the different levels of $\mathrm{P}+\mathrm{AMF}$ inoculated plants and different levels of P+ non AMF plants. The total colchicine content of plant (mg / plant), was significantly high in plants inoculated with Glomus mossae and $25 \mathrm{mg} \mathrm{kg}^{-1}$ phosphorus fertilizer (348.9 mg /plant), while the control contain least colchicine (177.87 mg / plant), (Fig.IIIA and B). The study suggests a potential role of AM fungi in improving the concentration of colchicine in Gloriosa superba tuber.

\section{Discussion}

The results clearly demonstrate high AM effectiveness in increasing the plant growth. The response of G. mossae was better than $G$. fasciculatum and other AMF inoculated plants. The effect of mycorrhiza on plant development is influenced mainly by both the host plant and fungal partner (Bethlenfalvay et al., 1989). Jackobsen et al. (1992) showed that different isolates of AM fungi can result in different effects on plant growth. The P-concentration of mycorrhizal plant varied with AM fungal inoculum. The results indicate marked differences in capacity of fungal species for the uptake of $\mathrm{P}$ by hyphae. This finding is in accordance with observations of Pearson and Jakobsen (1993). The colchicine content also varies among plants inoculated with different strains of AM Fungi. This finding is in accordance with Abu-Zeyad et al (2005) observed that castanospermine content in Castanospermum australe root are enhanced in the presence of AMF. Pandey and Banik (2009) found Glomus mossae to be the efficient AM fungi involved in enhancing growth and barbaloin content in Aloe vera

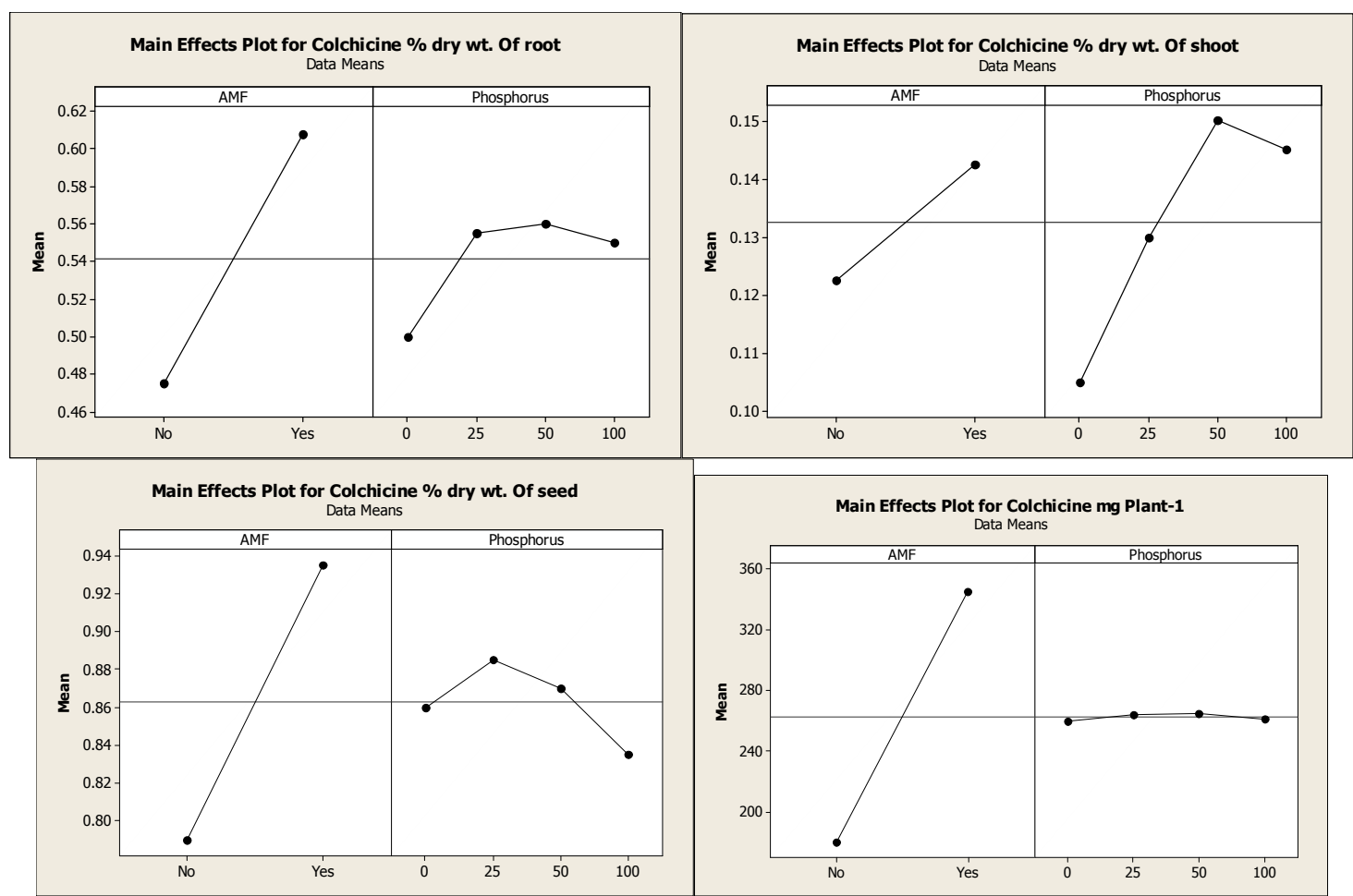

Figure III-A: Main effect plot of different AM fungi and phosphorus on colchicine content of Gloriosa superba

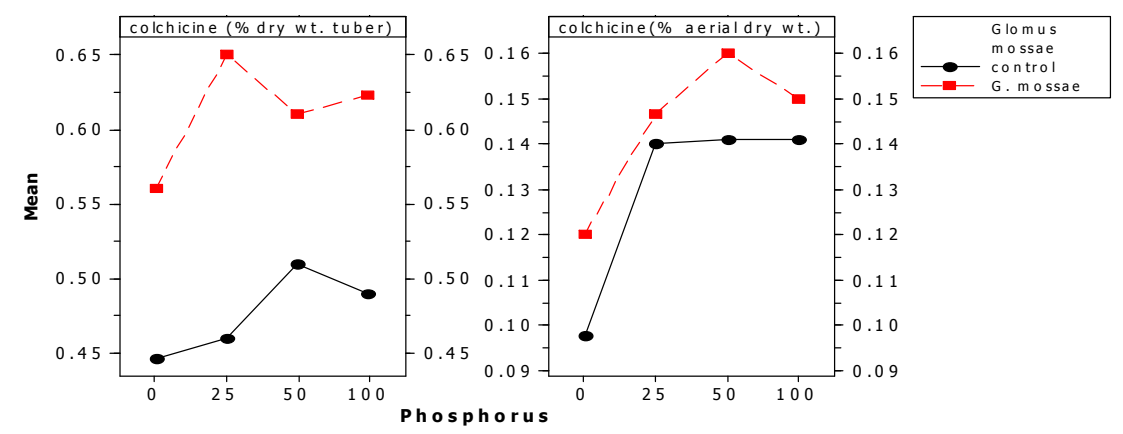


Pandey et al., Afr J Tradit Complement Altern Med. (2014) 11(2):439-446

http://dx.doi.org/10.4314/ajtcam.v11i2.30

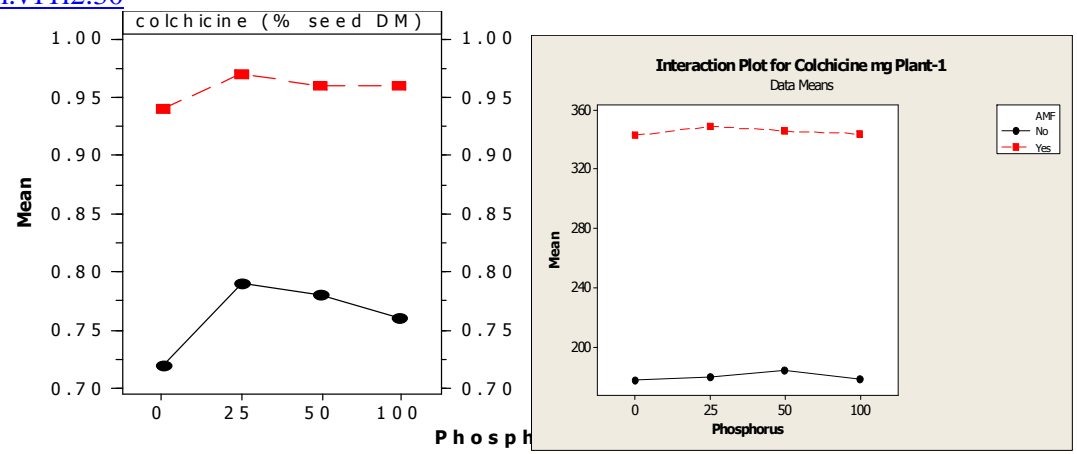

Figure III- B: Graph of different AM fungi and phosphorus on colchicine content of Gloriosa superba

A significant increase in growth and colchicine concentration in Gloriosa superba was recorded in plants from all treatments relative to the controls. Increased growth and development in AM plants compared to non-mycorrhizal ones has been reported for many plant species, including members of Liliaceae (Bryla and Duniway 1997; Ultra et al. 2007). Different effects on plant development were observed depending on the fungal species and P-status of the soil. Glomus mossae-inoculated plants registered higher yield at different levels of phosphorus in soil. The greatest growth effect was observed with Glomus mossae in the P-enriched $\left(50 \mathrm{mg} \mathrm{kg}^{-1}\right)$ soil. The plant given combined treatment of phosphate and mycorrhizal inoculation could utilize the maximum benefits of phosphate fertilizer inspite of their decreased AM colonization in roots. Mycorrhization or Pfertilization alone did not influence the concentration of photosynthetic pigments. These results are not in agreement with results obtained in some earlier works (Giri et al. 2003; Kapoor and Bhatnagar 2007). Taiz and Zeiger (1998) correlated enhanced concentrations of chlorophyll to Cu uptake. $\mathrm{Cu}$ is involved in the electron transport system and is a component of the chlorophyll protein plastocyanin. Thus, significant differences in concentrations of chlorophyll-a and chlorophyll-b observed in the present study may be attributed to similar Cu concentrations in leaves of AMinoculated and nonmycorrhizal plants.

Colchicine has been reported to accumulate in tuber and other parts of the Gloriosa superba plants (Ferreira and Janick 1995). Therefore, substances that improve tuber and shoot growth are presumed to increase colchicine yield. Moreover, biosynthesis of colchicine is dependent on primary metabolism, e.g., photosynthesis and oxidative pathways for carbon and energy supply (Singh et al. 1990). According to Fitter (1988) and Giri et al. (2003), net photosynthesis of mycorrhizal plants can increase as a result of improved plant nutritional status. Factors that increase dry matter production may influence the interrelationship between primary and secondary metabolism, leading to increased biosynthesis of secondary products (Shukla et al. 1992). It appears that significant improvement in plant biomass results in greater availability of substrate for colchicine biosynthesis (van Gelgre et al. 1997). The enhanced concentration of colchicine by mycorrhization and/or P-fertilization may be due to improved growth and nutrient status of the plants. Consequently, the increase in colchicine concentration depends on the species of AM fungus used, with $G$. mossae being a more efficient symbiont for Gloriosa superba than G. fasciculatum and other species of Gigaspora.

In conclusion, the present study demonstrates the effectiveness of AM fungi in improving the concentration of colchicine in Gloriosa superba. Inoculation with suitable AM fungal species along with P-fertilization produces significant increases in tuber biomass production, resulting in significant increases in colchicine content of individual plants. Thus, introduction of mycorrhizal technology in conjunction with P-fertilizers will be helpful in developing low-cost cultivation of Gloriosa superba and production of colchicine.

\section{Acknowledgements}

This research was funded by the Council of Scientific and Industrial Research, New Delhi, India.

\section{References}

1. Allen, S.E. (1989). Chemical analysis of ecological materials, 2nd edn. Blackwell Scientific Publishers, Oxford, London.

2. Angelov, M.N., Sun, J., Byrd, G.T., Brown, R.H., and Black, C.C. (1993). Novel characteristics of cassava, Manihot esculenta Crantz, a reputed C3-C4 intermediate photosynthetic species. Photosynth Res., 38: 61-72.

3. Alexander, P., Brigitte, N., and Meinhart, Z. (1994). Immuno assays for the quantitative determination of colchicines. Planta Medica. 60: 77-83.

4. Bellet, P., Gaignault, Le J.C. (1985). Gloriosa superba L. et al production de substances colchiciniques. Ann. Pharm. Fr. 1985. 43: $345-347$.

5. Bodoki, E., Oprean, R., Vlase, L., Tamas, M., and Sandulescu, R. (2005). Fast determination of colchicine by TLC-densitometry from pharmaceuticals and vegetal extracts J. of Pharm.and Biomed. Anal. 37: 971-977.

6. Bremmer, J.M. and Mulvaney, C.S. (1982). Nitrogen-total. In: Page AL, Miller RH, Keeney DR (eds) Methods of soil analysis: chemical and microbiological properties. Part 2. 2nd edn. American Society of Agronomy, Madison, pp: 595-624.

7. Bryla, D.R., and Duniway, J.M. (1997). Effects of mycorrhizal infection on drought tolerance and recovery in safflower and wheat. Plant Soil. 197:95-103.

8. Clewer, H.W.V., Green, S.S., and Tutin, F. (1915). The constituents of Gloriosa superba. J. Chem. Soc. 107: 835-846.

9. Ferreira, J.F.S., and Janick, J. (1995). Floral morphology of Artemisia annua with special reference to trichomes. Int J Plant Sci. 156:807-815.

10. Finnie, J.F., and van Staden, J. ( 1989). In vitro production of Sandersonia and Gloriosa. Plant Cell Tiss. Organ Cult. 19: 151-158.

11. Finnie, J.F., and van Staden, J. (1991). Isolation of colchicine from Sandersonia aurantica and Gloriosa superba. Variation in the alkaloid levels of plants grown in vivo. J. Plant Physiol. 138: 691-695.

12. Finnie, J.F., and Van Staden, J. (1994). Gloriosa superba L. (Flame Lily): micropropagation and in vitro production of colchicines. In: Bajaj, Y.P.S. (Ed.), Biotechnology in Agriculture and Forestry, vol. 26: Medicinal and Aromatic Plants VI, (Chapter X),. pp. $146-166$. 
http://dx.doi.org/10.4314/ajtcam.v11i2.30

13. Fitter, A.H. (1988). Water relations of red clover Trifolium pretense L. as affected by VA mycorrhizal infection and phosphorus supply before and during drought. J Exp Bot., 202:595-603.

14. Shukla, A., Abad Farooqi. A.H., Shukla. Y.N., and Sharma, S. (1992). Effect of triacontanol and chlormequat on growth, plant hormones and artemisinin yield in Artemisia аппиа L. Plant Growth Regul. 11:165-171.

15. Giovannetti, M., and Mosse, B. (1980). An evaluation of techniques for measuring vesicular and arbuscular mycorrhizal infection in roots. New Phytologist. 84: 489-500.

16. Giri, B., Kapoor, R., and Mukerji, K.G. (2003). Influence of arbuscular mycorrhizal fungi and salinity on growth, biomass and mineral nutrition of Acacia auriculiformis. Biol Fertil Soils. 38:170-175.

17. Goldfinger, S.E. (1972). Colchicine for familial Mediterranean fever. J. Med. 287: 1302.

18. Harborne, J.B. (1973). Recommended techniques, chlorophyll estimation. In: Harborne JB, editor. Phytochemical methods. London, UK. p. 2057.

19. Hayashi, T., Yoshida, K., and Sano, K. (1988). Formation of alkaloids in suspension cultured Colchicum autumnale. Phytochemistry., 27: 3711374.

20. Kapoor, R., and Bhatnagar, A.K. (2007). Attenuation of cadmium toxicity in mycorrhizal Celery (Apium graveolens L.). World J Microbiol Biotechnol.23: 1083-1089.

21. Kapoor, R., Giri, B., and Mukerji, K.G.( 2002a). Glomus macrocarpum: a potential bioinoculant to improve essential oil quality and concentration in dill (Anethum graveolens L.) and carum (Trachyspermum ammi (Linn.) Sprague). World J Microbiol Biotechnol. 18:459-463.

22. Kapoor, R., Giri, B., and Mukerji, K.G. (2002b). Mycorrhization of coriander (Coriandrum sativum L.) to enhance the concentration and quality of essential oil. J Sci Food Agric. 88:1-4.

23. Kapoor, R., Giri, B., and Mukerji, K.G.( 2004). Improved growth and essential oil yield and quality in Foeniculum vulgare Mill. on mycorrhizal inoculation supplemented with P-fertilizer. Bioresour Technol. 93(3). 307-3011.

24. Kershenobich, D., Varga, F., Garcia Tao, G., Tamayo, R.P., Gent, M., and Rojkind, M. (1988).Colchicine in the treatment of cirrhosis of the liver. N. Engl. J. Med.318: 1709-13.

25. Khaosaad, T., Vierheilig, H., Nell, M., Zitterl-Eglseer, K., and Noval, J. (2006). Arbuscular mycorrhiza alter the concentration of essential oils in oregano (Origanum sp., Lamiaceae). Mycorrhiza. 16:443-446.

26. Owusu-bennoah, E., and Mossae, B. (1979). Plant growth responses to vesicular-arbuscular mycorrhiza. XI. Field inoculation responsesin barley, Lucerne and onion, New phytologist, 83: 133-140.

27. Pandey, D.K. and Banik, RM.( 2009). The Influence of Dual Inoculation with Glomus mossae and Azotobacter on Growth and Barbaloin Content of Aloe vera. Am.-Eu. J. Sust. Agric.. 3(4): 703-714.

28. Phillips, J.M, and Hayman, D.S.( 1970). Improved procedures for clearing roots and staining parasitic and vesicular arbuscular mycorrhizal fungi for rapid assessment of infection. Trans Br Mycol Soc. 55: 158-160.

29. Riazi, A., K., Matsuda, A., and Aslan, (1985). Water stress induced changes in concentration of praline and other solutes in growing regions of young barley leaves. J Exp. Botany, 172: 1716-1725.

30. Roberts, W.N., Liang, M.H., and Stern, S.H.( 1920). Colchicine in acute gout: reassessment of risks and benefits. J. Am. Med. Assoc. 257:. p2.

31. Sailo, G.L., and Bagyaraj, D.J. (2005). Influence of different AM-fungi on the growth, nutrition and forskolin content of Coleus forskohlii. Mycol Res. 109:795-798.

32. Sarin, Y.K., Jamwal, P.S., Gupta, B.K., and Atal, C.K.( 1977). Colchicine from seeds of Gloriosa superba. Curr. Sci. $43: 87$.

33. Singh N., Luthra R., and Sangwan R.S. (1990). Oxidative pathway of essential oil biosynthesis in the developing Cymbopogon flexuosus leaf. Plant Physiol Biochem. 28:703-710.

34. Smith, F.A., Jakobsen, I., and Smith, S.E.(2000). Spatial differences in acquisition of soil phosphate between two arbuscular mycorrhizal fungi in symbiosis with Medicago truncatula. New Phytol. 147:357-366.

35. Srivastava ,U.C., and Chandra, V.( 1977). Gloriosa superba Linn. (kalihari) an important colchicine producing plant. J. Res. Ind. Med.. 10: 92-95.

36. Taiz, L., and Zeiger, E. (1998). Plant physiology, 2nd edn. Sinauer, Sunderland. 251-286.

37. Trease, S.E., and Evans, D. (1983) Pharmacognosy, Colchicum Seed and Corm, 12th Edn., WB Saunders Co. Ltd, London, UK..pp. 593-597,

38. Ultra, V., Tanaka, S., Sakurai, K., and Iwasaki, K. (2007). Effects of arbuscular mycorrhizal and phosphorus application on arsenic toxicity in sunflower (Helianthus annuus 1.) and on the transformation of arsenic in the rhizosphere. Plant Soil. 290:29-41.

39. Van Gelgre, E., Vergauwe, A., and van den, Eeckhout E.( 1997). State of the art of the production of the antimalarial compound artemisinin in plants. Plant Mol Biol.33:199-209.

40. Yoshida, K., Hayashi, T., and Sano, K. (1988a). Colchicoside in Colchicum autumnale bulbs. Agric. Biol. Chem. 52: 593-594.

41. Yoshida, K., Hayashi, T., and Sano, K. (1988b). Colchicine precursors and the formation of alkaloids in suspension cultured Colchicum autumnale. Phytochem. 27: 1375-1378. 